\title{
How to Invest in Stocks of Family Business Groups? Case Study
}

\section{of WALSIN Group in Taiwan}

\author{
Yu-Wei $\operatorname{Lan}^{1 *}$, Dan $\operatorname{Lin}^{1} \&$ Lu Lin ${ }^{2}$ \\ ${ }^{1}$ Department of Banking and Finance, Takming University of Science and Technology, Taipei, Taiwan \\ ${ }^{2}$ Department of Public Finance and Taxation, Takming University of Science and Technology, Taipei, \\ Taiwan \\ *Yu-Wei Lan, E-mail: ywlan@takming.edu.tw
}

Received: July 15, 2017

Accepted: July 26, 2017

Online Published: July 28, 2017

doi:10.22158/rem.v2n3p105

URL: http://dx.doi.org/10.22158/rem.v2n3p105

\begin{abstract}
The impact of family business groups on the industry has drawn different views. A major challenge for investors is to understand the business model of enterprises and enhance the trading performance in the financial market. Using the data of WALSIN family group, this article adopts generalized autoregressive conditional heteroscedasticity model (EGARCH) to investigate the volatility of stock prices of WALSIN family group.

The overall evidence suggests that the relationship between the leverage effect after including the leading company variable and the absence of the leading company appears to be significant at the $1 \%$ level. Therefore, the leverage effect after including the leading company has a certain effect on the financial operation of the family business group. In other words, it is helpful to include the leverage effect of the leading company in the portfolio, which can stabilize the trading performance of the WALSIN family group.

Furthermore, this study adopts Granger causality and program trading to test the strategy of following the leader of WALSIN family group. The net trading profit during this period is $71.03 \%$. The results show that the technical analysis tested in this study can lead to trading profits and investors can increase their trading profits by following the leader in the family owned business.
\end{abstract}

\section{Keywords}

family business, EGARCH, herd effect, Granger causality test, symmetric trading

\section{Introduction}

Since 2012, Taiwan family businesses were included in the global investigation by the Family Business Survey. The survey showed that Taiwan family businesses were more conservative in comparison to other global family businesses when considering passing on the business to the next generation. The 
results in 2016 showed that $58 \%$ of Taiwan family businesses were reluctant to pass on the management role to external professionals whereas the global statistic was only $39 \%$. This suggests that the corporate governance of Taiwan family businesses is facing a great challenge (Note 1).

La Porta et al. (1999) use a control index as a standard for deciding whether a company is a family business. However, the dividing point of $10 \% \sim 40 \%$ is debatable. Once the final controlling family or person holds more than that percentage, this company is classified as a family business group. Johannisson and Huse (2000) believe that the founder of family business can enhance the cohesion in the company and improve the operational efficiency of the organization, thereby lowering the management cost. Family business tends to use "enterprise group" as a way of controlling their related businesses. For example, by being the chairman of board of directors or managing director, the founder can ensure that the family possesses a certain number of seats on the board. Other ways of ensuring the control include pyramid holding, cross holding and equity pledge. It can, on the one hand, reduce the risks by lowering the transparency of the company and, on the other hand, enhance the external resources and gain the complementary effect. The enterprise groups have some potential advantages compared to individual companies, such as more capital and internal trading. This business model is mimicked by many businesses. Apart from controlling the number of management roles, Finkelstein (1992) finds that family members use a number of different ways to consolidate their power. For example, they will extend the tenure to enhance their power structure and focus more on the business' long-term development.

Jain and Kini (2000) argue that if the board members are occupied by family members, it is likely to limit the company's resource network. La Porta et al. (1999) investigate the top 20 companies of 27 countries and find that the controlling stockholders of the enterprise group like to use pyramid holding structure to control companies within the group and drain funds from the bottom companies to exploit small stockholders. Johnson et al. (2000) also find that controlling stockholders of the enterprise group have strong motives to transfer internal company resources to outside in order to increase their own wealth. Moreover, Bae et al. (2002) and Baek et al. (2004) find that controlling stockholders of the enterprise group tend to use insider trading or take the advantage of asset restructuring to transfer company resources to controlling stockholders. These acts are likely to affect the company's stock prices. Therefore, rather than focusing on corporate governance issues, this study looks directly at the stock performance of enterprise groups to search for good investment opportunities.

The case company investigated in this study is WALSIN. The founder is Jiao, Ting Biao who was the factory director of PEWC and chairman of WALSIN board. Jiao used the money made from his main business, WALSIN, and reinvested in stock markets, real estates and other subsidiary companies. Jiao had four sons and one daughter and the family table is presented in the Appendix (Note 2).

According to the statistics by Financial Supervisory Commission (Taiwan), individual investors' holdings in Taiwan's stock market have fallen from around $70 \%$ to less than $50 \%$. This is because individual investors have lost their confidence. They often "buy high and sell low" and make a loss. 
Therefore, this study adopts the behavioral finance theory to simulate program trading strategies. This can help individual investors trade the stocks of family groups. The organization of the paper is as follows. Section 2 is the literature review. Section 3 discusses the EGARCH model, Granger causality and the estimation method for program trading. Section 4 describes that data source. Section 5 presents that empirical results and analyses. Finally, the conclusion is presented in the last section.

\section{Literature Review}

The literature on stock market predictions can trace back to the random walk theory proposed by Bachelier (1900) who argues that the stock market volatility is similar to the Brownian motion in Physics. Later, Samulson (1965) from the perspective of Modern Economics suggests that stock prices are unpredictable if all information and anticipations of the market participants are included. Fama (1965) proposes that stock market prices are random. Fama (1970) then summaries the past literature and formally proposes an Efficient Market Hypothesis (EMH); that is, a weak form, semi-strong form and strong form of market efficiency.

After 1980s, empirical evidence shows anomalies exist in the market. For example, Shiller (1981) finds that the results from NYSE listed companies are inconsistent with the CAPM model of Sharp (1964); that is, the equity premium puzzle and over-reaction puzzle. Other anomalies include the size effect (Banz, 1981), season effect (Lakonishok et al., 1988), calendar effect (Cadsby, 1989) and IPO underpricing puzzle (Reilly et al., 1969). In addition, there are anomalies caused by investors' perception bias, such as anchoring effect, availability heuristics, intuitive heuristics, confirmation bias and framing dependence bias, and investors' psychological characteristics, such as overconfidence, ambiguity aversion, loss aversion, disposition effect and herding effect. Therefore, according to the behavior finance, investors have "bounded rationality".

Compared with the traditional financial theory, behavioral finance does not have well-structured pricing and investment portfolio theory. Some important breakthroughs in the field include the BAPM (behavior asset pricing model) of Shefrin and Statman (1994). Barberis, Shleifer and Visney (1998) argue that investors often over- or under-react. This changes the predictability of nonsystematic risks and therefore, gives rise to a predictable investment return model (that is, the BSV model). Daniel, Hirsheifer and Subrahmanyam (1998) divide investors into informed and uninformed groups and investigate the continuity in short-term stock returns and the long-term reversion (that is, the DHS model). Moreover, William and Huang (1995) examine two basic benchmarks in herding effect, stock market returns and dispersion in investment portfolio returns. The smaller the dispersion, the more prominent the herding effect. Investors often conduct noise trading or positive feedback trading. The latter is caused by herding trading behavior, extrapolative expectation and technical analyses. As institutional investors are more informed about their industry partners and have higher ability in prediction, they are more likely than individual investors to have herding trading behavior. In the situation of a lack of information, mimicking the trading behavior of others can reduce the costs of 
gathering information. Also, when making losses, investors can shirk responsibility, blame others and have less regrets. As herding behavior involves many investors, it has great impacts on the market stability and efficiency (Kim \& Wei, 1999). Previous studies on herding effect include Lakonishok et al. (1992) who study stock funds in the US between 1985 and 1989, Froot et al. (1994) who study the herding behavior of institutional investors and Werners (1999) who studies the herding behavior of mutual funds using a larger sample (between 1975 and 1994).

To investigate the complex behavior of financial markets that emerge from decisions made by many traders, Alanyalil et al. (2013) explore past issues of the Financial Times during the period 1992-2004 and quantify the relationship between decisions taken in financial markets and developments in financial news. They find a positive correlation between the number of times a company is mentioned in the Financial Times and the daily transaction volume of the company's stock. Their results provide quantitative supports for the links between the movements in financial markets and financial news. Furthermore, using transaction data of Ashland Inc. (listed on NYSE) in 1995, Cipriani (2014) builds a model of informational herding to examine herd behavior in financial markets. In the model, rational herding arises when there is information-event uncertainty. Herding occurs very often and is particularly pervasive on some days. On average, the proportion of herd buyers is $2 \%$; the proportion of herd sellers is $4 \%$. Herding also causes informational inefficiencies, accounting to four percent of the asset's expected value which might be the potential source of profits. Utilizing a time-varying transition probability Markov-switching model, Balcilar et al. (2015) examine the role of global risk factors on investor behavior in Borsa Istanbul, which is dominated largely by foreign investors. The results show that U.S. market-related factors are found to dominate regime transitions and contribute significantly to herd behavior in all market sectors with the exception of industrials. The results suggest that industrials are relatively immune to global shocks.

As for the mean reversion effect, some investors mistake that this effect exists in a short and mid-term period. De Bondt et al. (1985) find that good performing stocks in the previous year also perform better than the bad performing stocks in the following year. They also find a revision effect in stock market returns in the long-run. Fama and French (1988) analyze the NYSE listed stocks between 1926 and 1985 and find that in the long-term, stocks are negatively serial correlated, but positively serial correlated in the short-term. Poterba and Summers (1988) also find similar results using a different sample period and data from more countries. Moreover, Jegadeesh and Timan (1993) report momentum effects in the short and mid-term. Rouwenhourst (1998) adopts Jegadeesh et al.'s (1993) methods and find similar results in 12 European countries. Further, Conrad and Kaul (1988) show that adopting a reversion trading strategy in the long-term and a momentum strategy in the mid-term is a successful trading strategy.

All the above suggests that anomalies exist in the market. Hence, this study proposes a new testing method. Specifically, we use econometric models and optimized program trading and the trading strategy proposed by behavioral finance to conduct two stages of tests in order to find an investment 
strategy for investing family-owned business groups. The hypothesis tested is as follows:

After selecting a leading company in the industry, we can use technical analyses to enhance the trading performance of family-owned business groups.

\section{Research Methods}

\subsection{Theoretical Models and Estimation Methods of VAR and Granger Causality}

Sim (1980) applies the vector autoregression model in econometrics to ensure that all variables in the model have causal relationships and to avoid the identification problem in simultaneous structural equations. In the following program trading model, the three variables included are the stock prices of HannStar Board (Code: P5469), Taiwan 50 ETF (Code: P50) and WALSIN (Code: P1605). The variable in time $t$ is formed by the variable in the prior time $\mathrm{k}$ and the error term. For example, VAR (1) (i.e., $\mathrm{k}=1$ ) can be presented as:

$$
\begin{aligned}
& \text { P5469 }=\alpha_{1}+\mathrm{a}_{11} \text { P5469 }{ }_{\mathrm{t}-1}+\mathrm{a}_{12} \mathrm{P} 50_{\mathrm{t}-1}+\mathrm{a}_{13} \mathrm{P} 1605_{\mathrm{t}-1}+\varepsilon_{1 \mathrm{t}} \\
& \mathrm{P} 50_{\mathrm{t}}=\alpha_{2}+\mathrm{a}_{21} \mathrm{P} 469_{\mathrm{t}-1}+\mathrm{a}_{22} \mathrm{P} 0_{\mathrm{t}-1}+\mathrm{a}_{13} \mathrm{P} 1605_{\mathrm{t}-1}+\varepsilon_{2 \mathrm{t}} \\
& \mathrm{P} 1605_{\mathrm{t}}=\alpha_{2}+\mathrm{a}_{31} \mathrm{P} 469_{\mathrm{t}-1}+\mathrm{a}_{32} \mathrm{P} 0_{\mathrm{t}-1}+\mathrm{a}_{33} \mathrm{P} 1605_{\mathrm{t}-1}+\varepsilon_{2 \mathrm{t}}
\end{aligned}
$$

where $\mathrm{E}\left(\varepsilon_{\mathrm{t}}\right)=0, \forall \mathrm{t}, \mathrm{E}\left(\varepsilon_{\mathrm{t}} \varepsilon_{\mathrm{s}}^{\prime}\right)=\left\{\begin{array}{l}\Omega, \mathrm{s}=\mathrm{t} \\ 0, \mathrm{~s} \neq \mathrm{t}\end{array}, \Omega=\mathrm{E}\left(\varepsilon_{\mathrm{t}} \varepsilon_{\mathrm{t}}^{\prime}\right), \quad\right.$ The error term $\varepsilon_{\mathrm{t}}$ is white noise; $\mathrm{m}$ is the constant, a is the coefficient and $\Omega$ is the positive definite variable and covariance matrix. Granger $(1969,1988)$ and the application of Granger causality analysis proposed in Lan et al. (2017) can be used to clarify the relationship between the two.

\subsection{Theoretical Model and Estimation Method of EGARCH}

The Generalized Autoregressive Conditional Heteroscedasticity Model (GARCH) is developed by Bollerslev (1986) based on a modification of Engle's (1982) autoregressive conditional heteroscedasticity model $(\mathrm{ARCH})($ Note 3$)$. The $\mathrm{ARCH}$ model describes the random error distribution of information gathering $\psi_{\mathrm{t}-1}=\left\{\mathrm{y}_{\mathrm{t}-1}, \mathrm{x}_{\mathrm{t}-1}, \mathrm{y}_{\mathrm{t}-2}, \mathrm{x}_{\mathrm{t}-2}, \ldots\right\}$ in the previous period $\mathrm{t}-1$. The model is as follow:

$\varepsilon_{\mathrm{t}} \mid \psi_{\mathrm{t}-1} \sim \mathrm{N}\left(0, \mathrm{~h}_{\mathrm{t}}\right)$

$\mathrm{h}_{\mathrm{t}}=\alpha_{0}+\sum_{\mathrm{i}=1}^{\mathrm{q}} \alpha_{\mathrm{i}} \varepsilon_{\mathrm{t}-\mathrm{i}}^{2}$

where $\alpha_{0}>0, \alpha_{i} \geq 0, i=1, \ldots, n$ and GARCH (p, q) model overcome the condition of non-negative $\alpha$. Therefore, the model can be presented as below:

$$
\begin{gathered}
y_{t}=x_{t}^{\prime} \beta+\varepsilon_{t} \\
\varepsilon_{t}=\sqrt{h_{t}} v_{t}
\end{gathered}
$$




$$
h_{t}=\alpha_{0}+\sum_{i=1}^{q} \alpha_{i} \varepsilon_{t-i}^{2}+\sum_{j=1}^{p} \beta_{j} h_{t-j}
$$

where $h_{t}$ is the conditional variance of the GARCH model, $p$ is the order of GARCH terms $h^{2}$ and $q$ is the order of ARCH terms $\varepsilon^{2}$. As in finance, negative news often has greater impact on stock prices than positive news. The conditional variance of EGARCH model becomes:

$$
\ln \left(h_{t}\right)=\alpha_{0}+\sum_{j=1}^{p} \beta \operatorname{Ln}\left(h_{t-j}\right)+\sum_{i=1}^{q}\left(\alpha_{i}\left|\frac{\varepsilon_{t}}{\sqrt{h_{t}}}\right|+\gamma \frac{\varepsilon_{t}}{\sqrt{h_{t}}}\right)
$$

If the coefficient of leverage effect $r \neq 0$, it implies that there is an asymmetric response of conditional variance on positive error term and negative error term. From the volatility viewpoint, this study compares the impact on stock market when the data of WALSIN is included and excluded.

This study follows the method in Lan et al. (2014) and draws the news impact curve. The method is briefly described below:

1) Let $z=\frac{\mu}{\sigma}$. From the EGARCH model, we estimate the conditional variance series $\sigma^{2}$ and take the square root, which is then divided by the error term to derive $z$.

2) Rank $z$ from the lowest to the highest and structure a new series containing $z$.

3) Use the coefficients of the EGARCH model to derive $s$ :

$$
\log (\mathrm{s})=\alpha * \operatorname{abs}(\mathrm{z})-{ }^{\gamma} *_{\mathrm{z}}
$$

4) Plot $z$ and $s$ on a graph to draw the news impact curve and to observe the impact on the stock market. If the curve tilts upwards to the left with a large angle, it suggests a high degree of panic.

\subsection{Experimental Design and Estimation Method}

In traditional behavioral finance, there are two research methods in experimental designs. One is the Structural Equation Modeling (SEM) and the other is experimentation method. This study adopts a different method using Multi Charts to simulate a model for following leading company. In this study, the leading company is WALSIN in model 1 and HannStar Board in model 2. Data 2 is the price of 0050; Data 3 is the price of leading company. In addition, the trading strategy using RSI technical index in this study is based on the closing price and the breakthrough by the 20-day moving average. Three conditions of a "system buy" are: (1) today's closing price of data 2 is greater than 20-day moving average price of data 2; (2) today's closing price of data1 is greater than the 20-day moving average price of data1; and (3) the RSI of today's stock prices is higher than the best buying point's RSI (the simulation interval is 50 80). Conversely, three conditions of a "system sell" are: (1) today's closing price of data2 is lower than 20-day moving average price of data 2 ; (2) today's closing price of data1 is lower than the 20-day moving average price of data1; and (3) the RSI of today's stock prices is lower than the best selling point's RSI (the simulation interval is 20 40). We use the optimized trading to find the optimal number of days in moving average. The position is closed out if the profit is greater than 
500 points or the loss is greater than 100 points.

\section{Data}

Based on the information provided by Unique Business Weekly (Issue 1016, p. 14), WALSIN family business group includes WALSIN (1605), HannStar Board (5469), Walsin Technology (2492), HannStar (6116), gbm (6191), Winbond (2344), HannsTouch (3049), Walton Advanced Engineering (8110), PSA (6173), and Nuvoton (4919). As Nuvoton became public on 27 September 2010, the sample period for this study covers from 2010.9.27 2017.1.19 (i.e., a total of 2289 data sample). The data are obtained from daily stock price database of TEJ.

In order to ensure that the model is completed, the experiment is divided into two stages. The first stage covers from 2010.9.27 2013.10.31 and the second stage covers from 2010.9.27 2017.1.19. The second stage adopts optimal parameters from the first stage. The trading cost in the simulated models is assumed to be about $1 \%$ of the stock price.

\section{Results}

\subsection{Granger Causality Test of WALSIN}

\subsubsection{Unit Root Test of VAR Model Variables of WALSIN}

To ensure the validity of empirical results, we need to ensure that the series are stationary. Based on the testing steps of VAR model, we test for minimal AIC value. Taking WALSIN (P1605) as an example, the results show that when intercept is included $(-3.1170(0))$, it is a $\mathrm{I}(0)$ stationary series. However, when intercept and trend are considered $(-2.7740(0))$ or when no intercept and trend are considered $(-1.3614(0))$, null hypotheses are not rejected in both cases. That is, the series are not stationary, have fat tail and have autocorrelation. Therefore, I(0) is not stationary. After taking a difference, I(1) becomes stationary and rejects the null hypothesis (Table 1). Therefore, we can proceed with VAR and Granger causality test.

Table 1. Unit Root Test of VAR Model Variables of WALSIN

\begin{tabular}{|c|c|c|c|c|c|c|}
\hline \multirow{2}{*}{$\frac{\text { Model }}{\text { Variables Mode }}$} & \multicolumn{3}{|l|}{ Original Value } & \multicolumn{3}{|c|}{ First Order Difference } \\
\hline & Intercept & Intercept and Trend & Intercept & and Intercept & Intercept and Trend & No Intercept and Trend \\
\hline $\mathrm{P} 1605$ & $-3.1170(0)^{* *}$ & $-2.7747(0)$ & $-1.3614(0)$ & $-47.2318(0)^{*}$ & $-47.2562(0)^{*}$ & $-47.2370(0)^{*}$ \\
\hline P5469 & $-2.5494(1)^{* *}$ & $-2.3368(1)$ & $-1.5413(1)$ & $-43.5161(0)^{*}$ & $-43.5408(0)^{*}$ & $-43.5166(0)^{*}$ \\
\hline P2492 & $-0.8564(0)$ & $-1.4997(0)$ & $-0.2062(0)$ & $-46.5976(0)^{*}$ & $-46.8184(0)^{*}$ & $-46.6070(0)^{*}$ \\
\hline P6116 & $-2.0749(0)$ & $-1.8877(0)$ & $-1.3369(0)$ & $-47.2366(0)^{*}$ & $-47.2667(0)^{*}$ & $-47.2415(0)^{*}$ \\
\hline P6191 & $-4.6240(1)^{*}$ & $-4.0104(1)^{*}$ & $-3.8080(1)^{*}$ & $-44.8956(0)^{*}$ & $-45.0290(0)^{*}$ & $-44.8369(0)^{*}$ \\
\hline P2344 & $-2.1561(0)$ & $-2.9155(0)$ & $-0.5451(0)$ & $-47.8588(0)^{*}$ & $-47.8801(0)^{*}$ & $-47.8692(0)^{*}$ \\
\hline P3049 & $-1.8261(1)$ & $-2.1614(1)$ & $-0.8733(1)$ & $-44.4680(0)^{*}$ & $-44.4593(0)^{*}$ & $-44.4777(0)^{*}$ \\
\hline P8110 & $-2.6305(0)^{* *}$ & $-2.6008(0)$ & $-1.1342(0)$ & $-48.8262(0) *$ & $-46.8405(0)^{*}$ & $-46.8317(0)^{*}$ \\
\hline
\end{tabular}




\begin{tabular}{llllll}
\hline P6173 & $-1.7045(1)$ & $-1.6676(1)$ & $-0.9318(1)$ & $-43.5456(0)^{*}-43.5388(0)^{*}$ & $-43.5546(0) *$ \\
P50 & $--1.8478(0)$ & $-3.6836(0)^{* *}$ & $-0.2406(0)$ & $-47.8322(0)^{*}-47.8667(0)^{*}$ & $-47.8427(0)^{*}$ \\
\hline
\end{tabular}

Note: According to Mackinnon (1991), *,**,** shows significance level at $1 \%, 5 \%$ and $10 \%$. (0) shows that when the lag period is 0 , it has the minimal AIC. Sample code is as provided in Section 4.

\subsubsection{Lag Period Test of WALSIN's VAR Model}

Before proceeding with VAR model estimation, we must first test the lag period. The results show that the AIC, SC, HQ and FPE of WALSIN are at their minimum when the data is lagged one period (Table 2). Therefore, the VAR is estimated using lag period of one. According to AR roots graph, the reciprocals of the variables' unit roots are all within the circle (Figure 1). Therefore, the model is proven to be stationary.

Table 2. Lag Period Estimation of WALSIN's VAR Model

Included observations: 1562

\begin{tabular}{lllllll}
\hline Lag & LogL & LR & FPE & AIC & SC & HQ \\
\hline 0 & -37759.61 & NA & 27929884 & 48.36186 & 48.39956 & 48.37587 \\
1 & -3956.786 & 67086.27 & $5.21 \mathrm{e}-12^{*}$ & $5.235321^{*}$ & $5.687748^{*}$ & $5.403525^{*}$ \\
2 & -3840.475 & 229.1955 & $5.24 \mathrm{e}-12$ & 5.241325 & 6.108478 & 5.563716 \\
8 & -3263.612 & $183.4872^{*}$ & $6.35 \mathrm{e}-12$ & 5.432282 & 8.787784 & 6.679795 \\
\hline
\end{tabular}

Inverse Roots of AR Characteristic Polynomial

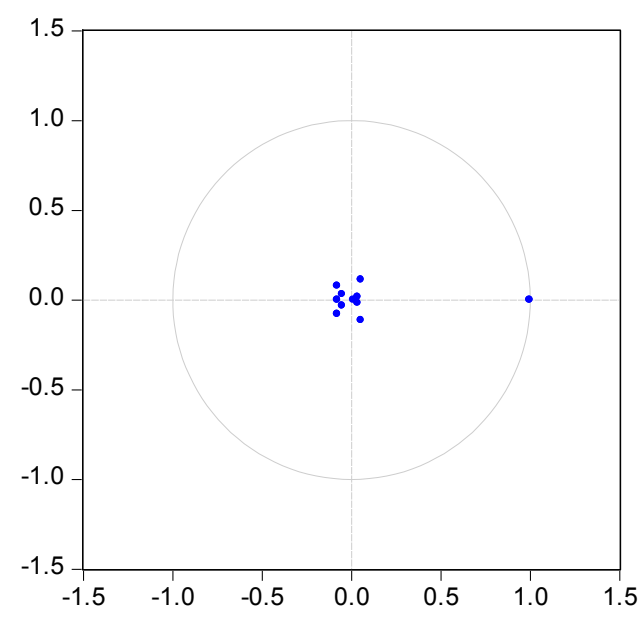

Figure 1. Stationary Test of AR Roots

\subsubsection{Granger Causality Test of WALSIN}

As VAR model can be used to investigate the relationship between variables that are unknown based on economic theories, this study includes the trading information of ten companies and Taiwan 50 ETF in 
the VAR model and conducts Granger causality test. The results show that when lagging one period, apart from Taiwan 50 ETF (7 times) and the undifferentiated P6191 (5 times) (Note 4), WALSIN (4 times) which has the highest average stock price is the Granger cause of other companies most often. Also, the investment behavior of four companies obviously includes the WALSIN's information as its endogenous variable (Table 3). In other words, the optimal investment behavior of four companies in the WALSIN business group refuses to reject the information of Taiwan 50 ETF and WALSIN. The information of Taiwan $50 \mathrm{ETF}$ and WALSIN is the Granger cause of other companies and causes herding behavior in other companies.

Table 3. Granger Causality Test of WALSIN

\begin{tabular}{|c|c|c|c|c|c|c|c|c|}
\hline \multicolumn{3}{|c|}{ Dependent variable: D(P1605) } & \multicolumn{3}{|c|}{ Dependent variable: D(P6173) } & \multicolumn{3}{|c|}{ Dependent variable: D(P2492) } \\
\hline Excluded & Chi-sq & Prob. & Excluded & Chi-sq & Prob. & Excluded & Chi-sq & Prob. \\
\hline $\mathrm{D}(\mathrm{P} 2344)$ & 2.047688 & 0.1524 & $\mathrm{D}(\mathrm{P} 1605)$ & 3.717566 & 0.0538 & $\mathrm{D}(\mathrm{P} 1605)$ & 0.042188 & 0.8373 \\
\hline $\mathrm{D}(\mathrm{P} 3049)$ & 1.904618 & 0.1676 & $\mathrm{D}(\mathrm{P} 2344)$ & 2.337512 & 0.1263 & $\mathrm{D}(\mathrm{P} 2344)$ & 0.356078 & 0.5507 \\
\hline $\mathrm{D}(\mathrm{P} 4919)$ & 2.027552 & 0.1545 & D(P3049) & 19.49493 & 0.0000 & $\mathrm{D}(\mathrm{P} 3049)$ & 0.205285 & 0.6505 \\
\hline $\mathrm{D}(\mathrm{P} 5469)$ & 0.861197 & 0.3534 & $\mathrm{D}(\mathrm{P} 4919)$ & 0.823400 & 0.3642 & $\mathrm{D}(\mathrm{P} 4919)$ & 0.035937 & 0.8496 \\
\hline $\mathrm{D}(\mathrm{P} 6116)$ & 0.280854 & 0.5961 & $\mathrm{D}(\mathrm{P} 5469)$ & 3.681953 & 0.0550 & D(P5469) & 0.139992 & 0.7083 \\
\hline $\mathrm{D}(\mathrm{P} 6173)$ & 0.042791 & 0.8361 & $\mathrm{D}(\mathrm{P} 6116)$ & 2.769121 & 0.0961 & $\mathrm{D}(\mathrm{P} 6116)$ & 0.018198 & 0.8927 \\
\hline $\mathrm{D}(\mathrm{P} 8110)$ & 0.001917 & 0.9651 & $\mathrm{D}(\mathrm{P} 8110)$ & 0.529163 & 0.4670 & $\mathrm{D}(\mathrm{P} 6173)$ & 0.759208 & 0.3836 \\
\hline $\mathrm{D}(\mathrm{P} 50)$ & 19.92865 & 0.0000 & $\mathrm{D}(\mathrm{P} 50)$ & 7.332551 & 0.0068 & $\mathrm{D}(\mathrm{P} 8110)$ & 1.223315 & 0.2687 \\
\hline $\mathrm{D}(\mathrm{P} 2492)$ & 0.523706 & 0.4693 & $\mathrm{D}(\mathrm{P} 2492)$ & 3.253310 & 0.0713 & $\mathrm{D}(\mathrm{P} 50)$ & 0.936548 & 0.3332 \\
\hline P6191 & 4.926773 & 0.0264 & P6191 & 14.69339 & 0.0001 & P6191 & 7.071177 & 0.0078 \\
\hline All & 37.91533 & 0.0000 & All & 69.62772 & 0.0000 & All & 13.11135 & 0.2175 \\
\hline \multicolumn{3}{|c|}{ Dependent variable: D(P2344) } & \multicolumn{3}{|c|}{ Dependent variable: D(P8110) } & \multicolumn{3}{|c|}{ Dependent variable: P6191 } \\
\hline Excluded & Chi-sq & Prob. & Excluded & Chi-sq & Prob. & Excluded & Chi-sq & Prob. \\
\hline $\mathrm{D}(\mathrm{P} 1605)$ & 0.514558 & 0.4732 & $\mathrm{D}(\mathrm{P} 1605)$ & 1.596865 & 0.2063 & $\mathrm{D}(\mathrm{P} 1605)$ & 0.007712 & 0.9300 \\
\hline D(P3049) & 0.752793 & 0.3856 & $\mathrm{D}(\mathrm{P} 2344)$ & 0.133447 & 0.7149 & $\mathrm{D}(\mathrm{P} 2344)$ & 0.029267 & 0.8642 \\
\hline $\mathrm{D}(\mathrm{P} 4919)$ & 0.001336 & 0.9708 & D(P3049) & 0.344086 & 0.5575 & D(P3049) & 3.995918 & 0.0456 \\
\hline D(P5469) & 1.824436 & 0.1768 & D(P4919) & 0.038957 & 0.8435 & $\mathrm{D}(\mathrm{P} 4919)$ & 0.449158 & 0.5027 \\
\hline $\mathrm{D}(\mathrm{P} 6116)$ & 0.894587 & 0.3442 & $\mathrm{D}(\mathrm{P} 5469)$ & 0.363386 & 0.5466 & D(P5469) & 1.113326 & 0.2914 \\
\hline $\mathrm{D}(\mathrm{P} 6173)$ & 0.382586 & 0.5362 & D(P6116) & 0.146233 & 0.7022 & $\mathrm{D}(\mathrm{P} 6116)$ & 0.054568 & 0.8153 \\
\hline $\mathrm{D}(\mathrm{P} 8110)$ & 0.320010 & 0.5716 & D(P6173) & 1.156281 & 0.2822 & $\mathrm{D}(\mathrm{P} 6173)$ & 0.010712 & 0.9176 \\
\hline $\mathrm{D}(\mathrm{P} 50)$ & 15.87387 & 0.0001 & $\mathrm{D}(\mathrm{P} 50)$ & 8.820565 & 0.0030 & $\mathrm{D}(\mathrm{P} 8110)$ & 2.531024 & 0.1116 \\
\hline $\mathrm{D}(\mathrm{P} 2492)$ & 0.427161 & 0.5134 & $\mathrm{D}(\mathrm{P} 2492)$ & 4.828526 & 0.0280 & $\mathrm{D}(\mathrm{P} 50)$ & 6.555826 & 0.0105 \\
\hline P6191 & 2.265528 & 0.1323 & P6191 & 1.405306 & 0.2358 & $\mathrm{D}(\mathrm{P} 2492)$ & 0.718960 & 0.3965 \\
\hline All & 21.40737 & 0.0184 & All & 19.05748 & 0.0395 & All & 23.51882 & 0.0090 \\
\hline
\end{tabular}




\begin{tabular}{|c|c|c|c|c|c|c|c|c|}
\hline \multicolumn{3}{|c|}{ Dependent variable: D(P3049) } & \multicolumn{3}{|c|}{ Dependent variable: $\mathbf{D}(\mathbf{P 5 0})$} & \multicolumn{3}{|c|}{ Dependent variable: $\mathrm{D}(\mathrm{P} 4919)$} \\
\hline Excluded & Chi-sq & Prob. & Excluded & Chi-sq & Prob. & Excluded & Chi-sq & Prob. \\
\hline $\mathrm{D}(\mathrm{P} 1605)$ & 4.914727 & 0.0266 & $\mathrm{D}(\mathrm{P} 1605)$ & 0.531514 & 0.4660 & $\mathrm{D}(\mathrm{P} 1605)$ & 8.099220 & 0.0044 \\
\hline $\mathrm{D}(\mathrm{P} 2344)$ & 0.119022 & 0.7301 & $\mathrm{D}(\mathrm{P} 2344)$ & 1.195931 & 0.2741 & $\mathrm{D}(\mathrm{P} 2344)$ & 0.010030 & 0.9202 \\
\hline $\mathrm{D}(\mathrm{P} 4919)$ & 2.046498 & 0.1526 & $\mathrm{D}(\mathrm{P} 3049)$ & 0.106021 & 0.7447 & D(P3049) & 0.042009 & 0.8376 \\
\hline $\mathrm{D}(\mathrm{P} 5469)$ & 0.012617 & 0.9106 & $\mathrm{D}(\mathrm{P} 4919)$ & 0.764814 & 0.3818 & $\mathrm{D}(\mathrm{P} 5469)$ & 2.968646 & 0.0849 \\
\hline $\mathrm{D}(\mathrm{P} 6116)$ & 0.320503 & 0.5713 & $\mathrm{D}(\mathrm{P} 5469)$ & 3.835505 & 0.0502 & $\mathrm{D}(\mathrm{P} 6116)$ & 0.004209 & 0.9483 \\
\hline $\mathrm{D}(\mathrm{P} 6173)$ & 2.080687 & 0.1492 & $\mathrm{D}(\mathrm{P} 6116)$ & 0.019747 & 0.8882 & $\mathrm{D}(\mathrm{P} 6173)$ & 29.67604 & 0.0000 \\
\hline $\mathrm{D}(\mathrm{P} 8110)$ & 1.067859 & 0.3014 & $\mathrm{D}(\mathrm{P} 6173)$ & 0.237914 & 0.6257 & $\mathrm{D}(\mathrm{P} 8110)$ & 0.819910 & 0.3652 \\
\hline $\mathrm{D}(\mathrm{P} 50)$ & 5.941374 & 0.0148 & $\mathrm{D}(\mathrm{P} 8110)$ & 0.123380 & 0.7254 & $\mathrm{D}(\mathrm{P} 50)$ & 0.185112 & 0.6670 \\
\hline $\mathrm{D}(\mathrm{P} 2492)$ & 1.175038 & 0.2784 & $\mathrm{D}(\mathrm{P} 2492)$ & 0.094969 & 0.7580 & $\mathrm{D}(\mathrm{P} 2492)$ & 0.640024 & 0.4237 \\
\hline P6191 & 2.592389 & 0.1074 & P6191 & 0.980967 & 0.3220 & P6191 & 2.184068 & 0.1394 \\
\hline All & 24.22809 & 0.0070 & All & 13.23183 & 0.2110 & All & 48.75191 & 0.0000 \\
\hline \multicolumn{3}{|c|}{ Dependent variable: D(P5469) } & \multicolumn{6}{|c|}{ Dependent variable: D(P6116) } \\
\hline Excluded & Chi-sq & Prob. & Excluded & Chi-sq & Prob. & & & \\
\hline $\mathrm{D}(\mathrm{P} 1605)$ & 3.544183 & 0.0598 & $\mathrm{D}(\mathrm{P} 1605)$ & 1.148385 & 0.2839 & & & \\
\hline $\mathrm{D}(\mathrm{P} 2344)$ & 0.109250 & 0.7410 & $\mathrm{D}(\mathrm{P} 2344)$ & 1.299603 & 0.2543 & & & \\
\hline $\mathrm{D}(\mathrm{P} 3049)$ & 5.762871 & 0.0164 & $\mathrm{D}(\mathrm{P} 3049)$ & 0.247668 & 0.6187 & & & \\
\hline $\mathrm{D}(\mathrm{P} 4919)$ & 0.039044 & 0.8434 & $\mathrm{D}(\mathrm{P} 4919)$ & 0.162043 & 0.6873 & & & \\
\hline $\mathrm{D}(\mathrm{P} 6116)$ & 0.764693 & 0.3819 & $\mathrm{D}(\mathrm{P} 5469)$ & 0.000105 & 0.9918 & & & \\
\hline $\mathrm{D}(\mathrm{P} 6173)$ & 3.466009 & 0.0626 & $\mathrm{D}(\mathrm{P} 6173)$ & 0.575153 & 0.4482 & & & \\
\hline $\mathrm{D}(\mathrm{P} 8110)$ & 0.079882 & 0.7775 & $\mathrm{D}(\mathrm{P} 8110)$ & 1.399276 & 0.2368 & & & \\
\hline $\mathrm{D}(\mathrm{P} 50)$ & 8.516380 & 0.0035 & $\mathrm{D}(\mathrm{P} 50)$ & 0.890884 & 0.3452 & & & \\
\hline $\mathrm{D}(\mathrm{P} 2492)$ & 3.731499 & 0.0534 & $\mathrm{D}(\mathrm{P} 2492)$ & 1.247815 & 0.2640 & & & \\
\hline P6191 & 5.933953 & 0.0149 & P6191 & 1.413015 & 0.2346 & & & \\
\hline All & 30.70604 & 0.0007 & All & 9.859693 & 0.4529 & & & \\
\hline
\end{tabular}

Note: Prob. means probability. Chi-sq is the $\chi^{2}$ statistics. Sample code is the same as Table 1. D means taking the first difference.

\subsection{Granger Causality Test of HannStar Board, Taiwan 50 ETF and WALSIN}

\subsubsection{Lag Period Test of HannStar Board, Taiwan 50 ETF and WALSIN}

Due to page limit, in this study we only include HannStar Board (p. 5469), Taiwan 50 ETF (p. 50) and WALSIN in the VAR model estimation. The first step is to examine the lagging period. The results show that the AIC and PFE of HannStar Board, Taiwan 50 ETF and WALSIN are at their minimum when lagging two periods (Table 4). Therefore, this model is estimated using a lag period of two. 
Table 4. Lagging Period Estimation of VAR Model of HannStar Board, Taiwan 50 ETF and WALSIN

\begin{tabular}{lllllll}
\hline Lag & LogL & LR & FPE & AIC & SC & HQ \\
\hline 0 & -1075.789 & NA & 0.000799 & 1.381292 & $1.391574^{*}$ & 1.385115 \\
1 & -1053.940 & 43.58712 & 0.000786 & 1.364839 & 1.405969 & $1.380131^{*}$ \\
2 & -1042.045 & 23.68339 & $0.000783^{*}$ & $1.361133^{*}$ & 1.433110 & 1.387892 \\
3 & -1035.093 & 13.81316 & 0.000785 & 1.363756 & 1.466580 & 1.401984 \\
4 & -1025.657 & $18.71664^{*}$ & 0.000785 & 1.363197 & 1.496868 & 1.412893 \\
\hline
\end{tabular}

\subsubsection{Granger Causality Test of HannStar Board, Taiwan 50 ETF and WALSIN}

The Granger causality test of HannStar Board, Taiwan 50 ETF and WALSIN shows that when lagging two periods, HannStar Board and Taiwan 50 ETF are the Granger cause of each other and are endogenous variables (Table 5). Taiwan 50 ETF is the Granger cause of WALSIN. WALSIN is the Granger cause of HannStar Board. In other words, these two variables refuse to reject the information of each other. Therefore, we can proceed with the next step of investment simulations.

Table 5. Granger Causality Test of HannStar Board, Taiwan 50 ETF and WALSIN

Dependent variable: D(P5469)

\begin{tabular}{lccc}
\hline Excluded & Chi-sq & df & Prob. \\
\hline D(P50) & 10.09950 & 2 & 0.0064 \\
D(P1605) & 9.104602 & 2 & 0.0105 \\
All & 18.14123 & 4 & 0.0012 \\
\hline Dependent variable: D(P50) & Chi-sq & df & Prob. \\
\hline Excluded & 4.994850 & 2 & 0.0823 \\
\hline D(P5469) & 1.152025 & 2 & 0.5621 \\
D(P1605) & 8.048565 & 4 & 0.0898 \\
All & Chi-sq & df & Prob. \\
\hline Dependent variable: D(P1605) & 2 & 0.2111 \\
\hline Excluded & 3.111109 & 2 & 0.0000 \\
\hline D(P5469) & 20.58868 & 4 & 0.0000 \\
D(P50) & 28.30917 & & \\
All & & 2 & \\
\hline
\end{tabular}

Note: Samples codes are the same as in Table 1. 


\subsection{EGARCH Model Estimation and News Impact Response}

\subsubsection{Estimation Results of EGARCH Model (Excluding WALSIN)}

The model in this section does not include WALSIN and shows that all variables are significant at the $1 \%$ level where $\alpha=1.458280, \beta=0.865143$ and $\gamma=-0.234075$. This suggests that the leverage effect has greater impacts on psychological panicking reaction when there is bad news. The leverage effect from good news can be presented as: $1.224205=(1.458280-0.234075)$. The leverage effect from bad news can be presented as: $1.692355=(1.458280+(-0.234075) *(-1)$ (Table 6$)$.

Table 6. Estimation Results of EGARCH Model (Excluding WALSIN)

\begin{tabular}{|c|c|c|c|c|}
\hline Variable & Coefficient & Std. Error & z-Statistic & Prob. \\
\hline @SQRT(GARCH) & -0.372128 & 0.030766 & -12.09548 & 0.0000 \\
\hline P6116 & -0.004633 & 0.002479 & -1.868877 & 0.0616 \\
\hline P6191 & 0.492524 & 0.005446 & 90.44460 & 0.0000 \\
\hline P8110 & 0.267639 & 0.005704 & 46.92427 & 0.0000 \\
\hline P6173 & -0.102232 & 0.002378 & -42.98555 & 0.0000 \\
\hline P4919 & 0.187096 & 0.001350 & 138.5390 & 0.0000 \\
\hline $\mathrm{P} 50$ & 0.039990 & 0.000911 & 43.88554 & 0.0000 \\
\hline P2344 & -0.148788 & 0.009148 & -16.26409 & 0.0000 \\
\hline P2492 & -0.078444 & 0.001497 & -52.39310 & 0.0000 \\
\hline \multirow[t]{2}{*}{ P3049 } & 0.020748 & 0.003742 & 5.544330 & 0.0000 \\
\hline & \multicolumn{4}{|c|}{ Variance Equation } \\
\hline $\mathrm{C}(11)$ & -1.406555 & 0.077633 & -18.11796 & 0.0000 \\
\hline$C(12)$ & 1.458280 & 0.090918 & 16.03943 & 0.0000 \\
\hline $\mathrm{C}(13)$ & -0.234075 & 0.064198 & -3.646144 & 0.0003 \\
\hline$C(14)$ & 0.865143 & 0.021562 & 40.12338 & 0.0000 \\
\hline R-squared & 0.714064 & \multicolumn{2}{|c|}{ Mean dependent var } & 13.49570 \\
\hline Adjusted R-squared & 0.712406 & \multicolumn{2}{|c|}{ S.D. dependent var } & 3.140465 \\
\hline S.E. of regression & 1.684162 & \multicolumn{2}{|c|}{ Akaike info criterion } & 2.133134 \\
\hline Sum squared resid & 4402.094 & \multicolumn{2}{|c|}{ Schwarz criterion } & 2.181119 \\
\hline Log likelihood & -1651.978 & \multicolumn{2}{|c|}{ Hannan-Quinn criter. } & 2.150974 \\
\hline Durbin-Watson stat & 0.029878 & & & \\
\hline
\end{tabular}

The next step is to draw the news impact curve from the EGARCH results (excluding WALSIN) (Figure 2). The Figure shows that when the news impact is less than 0 , the bad news impact curve is steeper and the good news impact curve is more flat. The results suggest that bad news will cause stock prices to become more volatile. That is, the sample without WALSIN faces greater risks. 


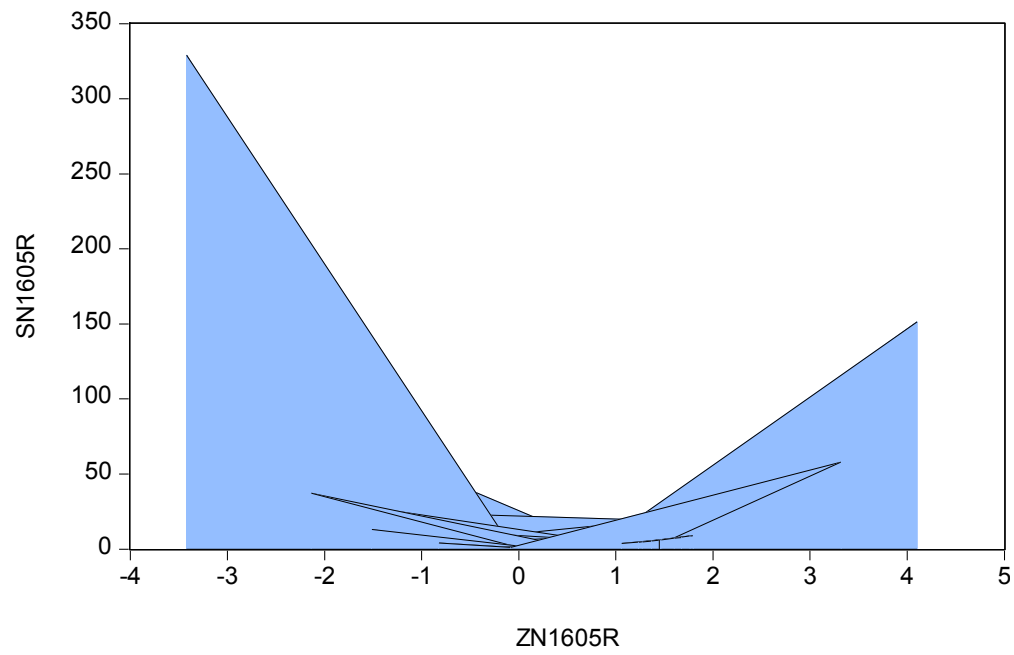

Figure 2. News Impact Curve Excluding WALSIN

\subsubsection{Estimation Results of EGARCH Model (Including WALSIN)}

The model including WALSIN is significant at the $1 \%$ level, where $\alpha=1.252025, \beta=0.814752$ and $\gamma=$ 0.167008 . The results show that the leverage effect does not have greater impacts on the psychological panicking reaction when there is bad news. The leverage effect from good news can be presented as: $1.419033=(1.252025+0.167008)$. The leverage effect from bad news can be presented as: $1.085017=$ $(1.252025+(0.167008) *(-1))($ Table 7$)$.

Table 7. EGARCH Model Results (Including WALSIN)

\begin{tabular}{lllll}
\hline Variable & Coefficient & Std. Error & z-Statistic & Prob. \\
\hline @SQRT(GARCH) & 0.265210 & 0.041131 & 6.447954 & 0.0000 \\
P5469 & -0.031578 & 0.005148 & -6.134397 & 0.0000 \\
P6116 & 0.034685 & 0.002614 & 13.26881 & 0.0000 \\
P6191 & 0.269533 & 0.006918 & 38.95860 & 0.0000 \\
P8110 & 0.182703 & 0.006454 & 28.30828 & 0.0000 \\
P6173 & 0.182697 & 0.002466 & 74.09076 & 0.0000 \\
P4919 & 0.076752 & 0.001439 & 53.33047 & 0.0000 \\
P50 & 0.017471 & 0.001146 & 15.24369 & 0.0000 \\
P2344 & -0.067861 & 0.008920 & -7.607506 & 0.0000 \\
P2492 & -0.007024 & 0.001391 & -5.049683 & 0.0000 \\
P3049 & -0.034723 & 0.003713 & -9.352007 & 0.0000 \\
\hline & Variance Equation & & & \\
\hline C(12) & -1.434912 & 0.130201 & -11.02077 & 0.0000 \\
C(13) & 1.252025 & 0.110015 & 11.38052 & 0.0000 \\
\hline
\end{tabular}




\begin{tabular}{|c|c|c|c|c|}
\hline $\mathrm{C}(14)$ & 0.167008 & 0.058182 & 2.870434 & 0.0041 \\
\hline$C(15)$ & 0.814752 & 0.030797 & 26.45571 & 0.0000 \\
\hline R-squared & 0.944651 & \multicolumn{2}{|c|}{ Mean dependent var } & 10.28562 \\
\hline Adjusted R-squared & 0.944294 & \multicolumn{2}{|c|}{ S.D. dependent var } & 2.788817 \\
\hline S.E. of regression & 0.658221 & \multicolumn{2}{|c|}{ Akaike info criterion } & 1.147801 \\
\hline Sum squared resid & 671.9774 & \multicolumn{2}{|c|}{ Schwarz criterion } & 1.199214 \\
\hline Log likelihood & -881.4329 & \multicolumn{2}{|c|}{ Hannan-Quinn criter. } & 1.166916 \\
\hline Durbin-Watson stat & 0.086912 & & & \\
\hline
\end{tabular}

Similarly, we can draw the news impact curve of EGARCH model (including WALSIN) (Figure 3). The Figure shows that when the news impact is less than 0 , the bad news impact curve is more flat and the good news impact curve is steeper. The results suggest that good news will cause stock prices to become more volatile. That is, the sample with WALSIN faces lower risks.

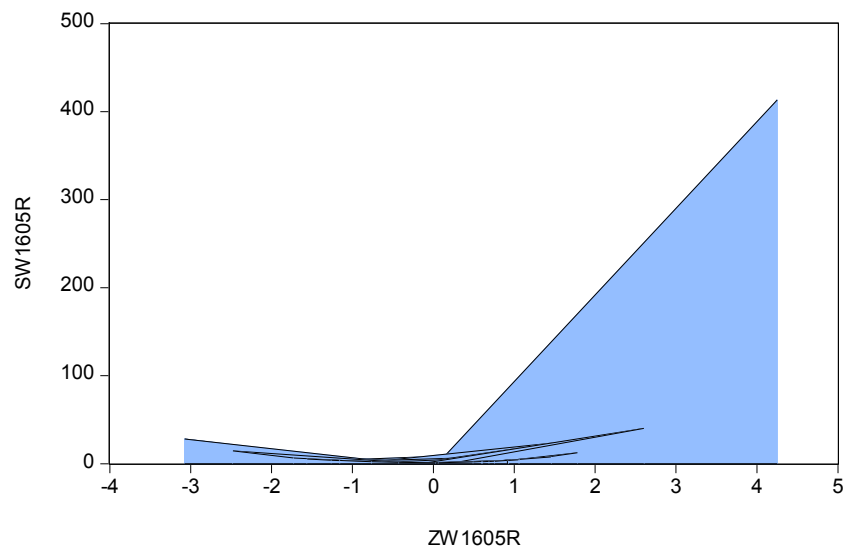

Figure 3. News Impact Curve Including WALSIN

\subsection{Comparison of WALSIN's Trading Strategy and Investment Performance}

This model is composed of the stock prices of the leading company and other individual stocks. That is, Data 1 is individual stock prices. Data 2 is the prices of Taiwan 50 ETF. Data 3 is the stock prices of the leading company, which is WALSIN in model 1 and HannStar Board in model 2. The results suggest that in model 1, only one company reduces the investment returns in stage two. If the investment portfolio includes the ten WALSIN business group companies, the trading is profitable (Table 8). Between 27 September 2010 and 31 December 2013, the profit from the investment portfolio is $\$ 62.47$. When the sample period is extended to 19 January 2017, the profit increases by $\$ 44.37$ (50.35\%), which is better than the overall market of $8.2 \%$. The results show that this program trading is profitable. 
Table 8. Investment Returns of Model 1 Where the Leading Company is WALSIN (Unit: Dollar,

Times, \%)

\begin{tabular}{|c|c|c|c|c|c|c|c|c|}
\hline \multirow{3}{*}{$\begin{array}{l}\text { Company } \\
\text { Code }\end{array}$} & \multicolumn{3}{|c|}{ 2010.9.27-2013.12.31 } & \multicolumn{3}{|c|}{ 2010.9.27-2017.1.19 } & \multirow{3}{*}{$\begin{array}{l}\text { Changes } \\
\text { in Profits }\end{array}$} & \multirow{3}{*}{$\begin{array}{l}\text { Total } \\
\text { Profits }\end{array}$} \\
\hline & \multirow{2}{*}{ Net Profit } & \multicolumn{2}{|c|}{ of Winn } & \multirow{2}{*}{$\begin{array}{l}\text { Net } \\
\text { Profit }\end{array}$} & \multirow{2}{*}{$\begin{array}{l}\text { No. } \\
\text { Transaction }\end{array}$} & of Winning & & \\
\hline & & Transaction & Probability & & & Probability & & \\
\hline P1605 & - & - & - & - & - & - & - & \\
\hline P5469 & 8.06 & 4 & 50 & 14.82 & 9 & 44 & 6.76 & \\
\hline P2492 & 8.33 & 13 & 69 & 6.94 & 39 & 38 & -1.39 & \\
\hline P6116 & 11.68 & 11 & 54 & 14.14 & 27 & 51 & 2.46 & \\
\hline P6191 & 4.06 & 13 & 46 & 12.8 & 31 & 48 & 8.74 & 44.37 \\
\hline P2344 & 14.47 & 10 & 80 & 19.39 & 27 & 59 & 4.92 & \\
\hline P3049 & 10.93 & 10 & 40 & 17.92 & 18 & 38 & 6.99 & \\
\hline P8110 & 4.05 & 15 & 33 & 7.86 & 34 & 32 & 3.81 & \\
\hline P6173 & 0.89 & 12 & 50 & 10.19 & 30 & 16 & 9.3 & \\
\hline
\end{tabular}

Note: The first stage covers the period 2010.9.27 2013.12.31. The second stage covers the period 2010.9.27 2017.1.19. Changes in profits cover the period 2013.12.31 2017.1.19.

The results show that only two companies in model 2 reduce investment returns in the second stage. If the investment portfolio includes ten WALSIN business group companies, the trading is profitable (Table 9). Between 27 September 2010 and 31 December 2013, the profit from the investment portfolio is $\$ 78$. When the sample period is extended to 19 January 2017 , the profit increases by $\$ 19.36$ (21.97\%), which is better than the overall market of $8.2 \%$ but worse than model $1(50.35 \%)$. The results suggest that the model with WALSIN as the leading company is better than the model with HannStar Board as the leading company.

Table 9. Investment Returns of Model 2 Where the Leading Company is HannStar Board (Unit: Dollar, Times, \%)

\begin{tabular}{llllllllll}
\hline \multirow{2}{*}{$\begin{array}{l}\text { Company } \\
\text { Code }\end{array}$} & \multicolumn{2}{l}{$2010.9 .27-2013.12 .31$} & \multicolumn{2}{l}{$2010.9 .27-2017.1 .19$} & & Changes & in Total \\
\cline { 2 - 7 } & Net & \multicolumn{2}{l}{ No. } & of Winning & Net & No. & of Winning & Profits & Profits \\
\hline P1605 & 5.23 & 3 & 100 & 8.75 & 9 & 60 & 3.52 & \\
P5469 & 7.69 & 4 & 75 & 11.47 & 12 & 41 & 3.78 & \\
P2492 & 7.55 & 16 & 50 & 5.65 & 45 & 33 & -1.9 & 19.36 \\
P6116 & 16.78 & 8 & 75 & 18.22 & 23 & 52 & 1.44 & \\
P6191 & - & - & - & - & - & - & - & \\
P2344 & 9.1 & 12 & 66 & 12.01 & 37 & 45 & 2.91 & \\
\hline
\end{tabular}




\begin{tabular}{llllllll}
\hline P3049 & 12.97 & 15 & 40 & 9.1 & 28 & 35 & -3.87 \\
P8110 & 5 & 1 & 100 & 14.18 & 10 & 40 & 9.18 \\
P6173 & 13.22 & 18 & 44 & 17.52 & 43 & 34 & 4.3 \\
\hline
\end{tabular}

Note: The first stage covers the period 2010.9.27 2013.12.31. The second stage covers the period 2010.9.27 2017.1.19. Changes in profits cover the period 2013.12.31 2017.1.19.

\section{Conclusion and Discussion on Investment Strategy}

Researchers have different views on the impact of family businesses on the industry. For investors, they must understand business models of enterprise groups in order to enhance their trading performance. This study analyses the impact of WALSIN family business group on the industry and examines the influences of leading company on the related family business companies.

The news impact curve based on the EGARCH model (including the leading company WALSIN) shows that when the news impact is less than 0 , the curve is more flat in the case of bad news. On the other hand, good news impact curve is steeper, suggesting that good news will cause greater volatilities in stock prices. That is, the risks are lower when WALSIN is included. The results suggest that including the leading company, WALSIN, in the investment portfolio is good for the stability of market trading.

Further, when including WALSIN and HannStar Board as the leading company in model 1 and 2, respectively and extending the examination period to 19 January 2017, the net profits increase by $50.35 \%$ and $21.97 \%$, respectively. The increment is larger than the overall market of $8.2 \%$. The results suggest that this program trading can lead to profits and model 1 is better than model 2 . Therefore, investors can employ the property of leading company to enhance their trading performance in financial markets. Due to the space and time limit, future research could study the stocks of other family groups in Taiwan to conduct optimal back testing and run the simulations.

\section{References}

Alanyali1, M., Moat, H. S., \& Preis, T. (2013). Quantifying the relationship between financial news and the stock market. Scientific Reports, 3. https://doi.org/10.1038/srep03578

Bachelier, L. (1900). Theory of speculation. In P. H. Cottner (Ed.), The Random Character of Stock Market Prices (pp. 17-78). MIT Press.

Bae, K., Kang, J., \& Kim, J. (2002). Tunneling or value added? Evidence from mergers by Korean business groups. Journal of Finance, 56(6), 2695-2740. https://doi.org/10.1111/1540-6261.00510

Baek, J., \& Kang, J. (2004). Corporate governance and firm value: Evidence from the Korean financial crisis. Journal of Financial Economics, 71(2), 265-313. https://doi.org/10.1016/S0304-405X(03)00167-3

Balcilar, M., \& Demirer, R. (2015). Effect of global shocks and volatility on herd behavior in an emerging market: Evidence from Borsa Istanbul. Emerging Markets Finance and Trade, 51(1), 
140-159. https://doi.org/10.1080/1540496X.2015.1011520

Banz, R. W. (1981). The relation between return and market value of common stocks. Journal of Financial Economics, 9, 3-8. https://doi.org/10.1016/0304-405X(81)90018-0

Barberis, N., Shleifer, A., \& Vishny, R. (1998). A model of investor sentiment. Journal of Financial Economics, 49, 307-345. https://doi.org/10.1016/S0304-405X(98)00027-0

Bollerslev, T. (1986). Generalized autoregressive conditional heteroscedasticity. Journal of Economics, 31, 307-327. https://doi.org/10.1016/0304-4076(86)90063-1

Cadsby, C. B. (1989). Canadian calendar anomalies and the capital asset pricing model. In R. M. C. Guimarães, B. G. Kingsman, \& S. J. Taylor (Eds.), A Reappraisal of the Efficiency of Financial Markets (Vol. 54). NATO ASI Series (Series F: Computer and Systems Sciences), Springer, Berlin, Heidelberg. https://doi.org/10.1007/978-3-642-74741-0_11

Cipriani, M., \& Guarino, A. (2014). Estimating a structural model of herd behavior in financial markets. The American Economic Review, 104(1), 224-251. https://doi.org/10.1257/aer.104.1.224

Conrad, J., \& Kaul, G. (1989). Time-variation in expected returns. Journal of Business, 61(4), 409-425. https://doi.org/10.1086/296441

Daniel, K., Hirshleifer, D., \& Subrahmanyam, A. (2001). Overconfidence, arbitrage and equilibrium asset pricing. Journal of Finance, 56, 921-965. https://doi.org/10.1111/0022-1082.00350

De Bondt, W. F. M., \& Thaler, R. H. (1985). Does the stock market overreact? Journal of Finance, 40(3), 793-805. https://doi.org/10.1111/j.1540-6261.1985.tb05004.x

De Long, J. B., Shleifer, A., Summers, L. H., \& Waldmann, R. J. (1990). Noise trader risk in financial markets. Journal of Political Economy, 98(4), 703-738. https://doi.org/10.1086/261703

Engle, R. F. (1982). Autoregressive conditional heteroskedasticity with estimates of the variance of United Kingdom inflation. Econometrica, 50, 987-1008. https://doi.org/10.2307/1912773

Fama, E. F. (1965). The behavior of stock-market prices. Journal of Business, 38(1), 34-105. https://doi.org/10.1086/294743

Fama, E. F. (1970). Efficient capital markets: A review of theory and empirical work. Journal of Finance, 25(2), 383-417. https://doi.org/10.2307/2325486

Fama, E. F., \& French, K. R. (1988). Dividend yields and expected stock returns. Journal of Financial Economics, 22(1), 3-25. https://doi.org/10.1016/0304-405X(88)90020-7

Finkelstein, S. (1992). Power in top management teams: Dimensions, measurement, and validation. Academy of Management Journal, 35(3), 505-538. https://doi.org/10.2307/256485

Froot, K. A., Scharfstein, D. S., \& Stein, J. C. (1993). Risk management: Coordinating corporate investment and financing policies. Journal of Finance, 48(5), 1629-1658. https://doi.org/10.1111/j.1540-6261.1993.tb05123.x

Granger, C. W. J. (1969). Investigating causal relations by econometric model and cross-spectral methods. Econometrica, 37, 24-36. https://doi.org/10.2307/1912791

Granger, C. W. J. (1988). Some recent development in the concept of causality. Journal of Published by SCHOLINK INC. 
Econometrics, 39, 199-211. https://doi.org/10.1016/0304-4076(88)90045-0

Jain, B. A., \& Kini, O. (2000). Does the presence of venture capitalists improve the survival profile of IPO firms? Journal of Business Finance and Accounting, 27(9-10), 1139-1183. https://doi.org/10.1111/1468-5957.00350

Jegadeesh, N., \& Timan, S. (1993). Returns to buying winners and selling losers: Implications for stock $\begin{array}{llll}\text { market efficiency. Journal of } & \text { Finance, }\end{array}$ https://doi.org/10.1111/j.1540-6261.1993.tb04702.x

Johannisson, B., \& Huse, M. (2000). Recruiting outside board members in the small family business: An ideological challenge. Entrepreneurship and Regional Development, 12(4), 353-378. https://doi.org/10.1080/08985620050177958

Johnson, S. R., La Porta, R., Lopez-de-Silanes, F., \& Shleifer, A. (2000). Tunneling. American Economic Review, 90, 22-27. https://doi.org/10.1257/aer.90.2.22

Kim, W., \& Wei, S. (2002). Foreign portfolio investors before and during a crisis. Journal of International Economics, 56(1), 77-96. https://doi.org/10.1016/S0022-1996(01)00109-X

La Porta, R., Lopez-de-Silanes, F., \& Shleifer, A., (1999). Corporate ownership around the world. Journal of Finance, 54(2), 471-518. https://doi.org/10.1111/0022-1082.00115

Lakonishok, J., \& Smidt, S. (1988). Are seasonal anomalies real? A ninety-year perspective. Review of Financial Studies, 1(4), 403-425. https://doi.org/10.1093/rfs/1.4.403

Lakonishok, J., Shleifer, A., \& Vishny, R. W. (1992). The impact of institutional trading on stock prices. Journal of Financial Economics, 32(1), 23-43. https://doi.org/10.1016/0304-405X(92)90023-Q

Lakonishok, J., Shleifer, A., \& Vishny, R. W. (1994). Contrarian investment, extrapolation, and risk. Journal of Finance, 49(5), 1541-1578. https://doi.org/10.1111/j.1540-6261.1994.tb04772.x

Lan, Y., Lin, D., \& Lin, L. (2014). How to invest safely in emerging markets during the global financial crisis: A case study of Taiwan. Global Journal of Management and Business Research, 14(4 Version 1.0), 29-41.

Lan, Y., Lin, D., \& Lin, L. (2017). The investment strategy of Taiwan futures market after quantitative easing monetary policy. Archives of Business Research, 5(3), 262-278. https://doi.org/10.14738/abr.53.2966

Poterba, J. M., \& Summers, L. H. (1988). Mean reversion in stock prices: Evidence and implications. Journal of Financial Economics, 22(1), 27-59. https://doi.org/10.1016/0304-405X(88)90021-9

Reilly, F. K., \& Hatfield, K. (1969). Investor experience with new stock issues. Financial Analysts Journal, 25(5), 73-80. https://doi.org/10.2469/faj.v25.n5.73

Rouwenhourst, G. (1998). International momentum strategies. Journal of Finance, 53, 267-284. https://doi.org/10.1111/0022-1082.95722

Samulson, P. (1965). Proof that properly anticipated prices fluctuate randomly. Industrial Management Review, 6, 41-49.

Shiller, R. J. (1979). The volatility of long-term interest rates and expectations models of the term 
structure. Journal of Political Economy, 87(6), 1190-1219. https://doi.org/10.1086/260832

Shiller, R. J. (1981). Do stock prices move too much to be justified by subsequent changes in dividends? American Economic Review, 71, 421-498.

Shiller, R. J. (1981). The use of volatility measures in assessing market efficiency. Journal of Finance, 36(2), 291-304. https://doi.org/10.1111/j.1540-6261.1981.tb00441.x

Sims, C. A. (1980). Macroeconomics and reality. Econometrica, 48, 1-48. https://doi.org/10.2307/1912017

Wermers, R. (1999). Mutual fund herding and the impact on stock prices. Journal of Finance, 54(2), 581-622. https://doi.org/10.1111/0022-1082.00118

William, G. C., \& Huang, R. D. (1995). Following the Pied Piper: Do Individual Returns Herd around the Market? Financial Analysts Journal, 54(4), 31-37.

Williams, L. (1999). Long-Term Secrets to Short-Term Trading. John Wiley \& Sons, Inc.

\section{Notes}

Note 1. Harvard Business Review (the global Chinese edition), May 2017, "Family asks: Are professional managers trust worthy?"

Note 2. Unique Business Weekly (2015/11/27), issue 1016, "Market trend during account settlement of enterprise group" (http://www.ettoday.net/news/20120218/25765.htm).

Note 3. This model solves the non-linear relationship in the variance of financial data that changes over time and the high kurtosis and fat tail volatility clustering problem.

Note 4. As some variables of the EGARCH model (exclusive of gbm (6191)) are not significant, we do not conduct chart analyses.

\section{Appendix 1}

Members of WALSIN Family Group

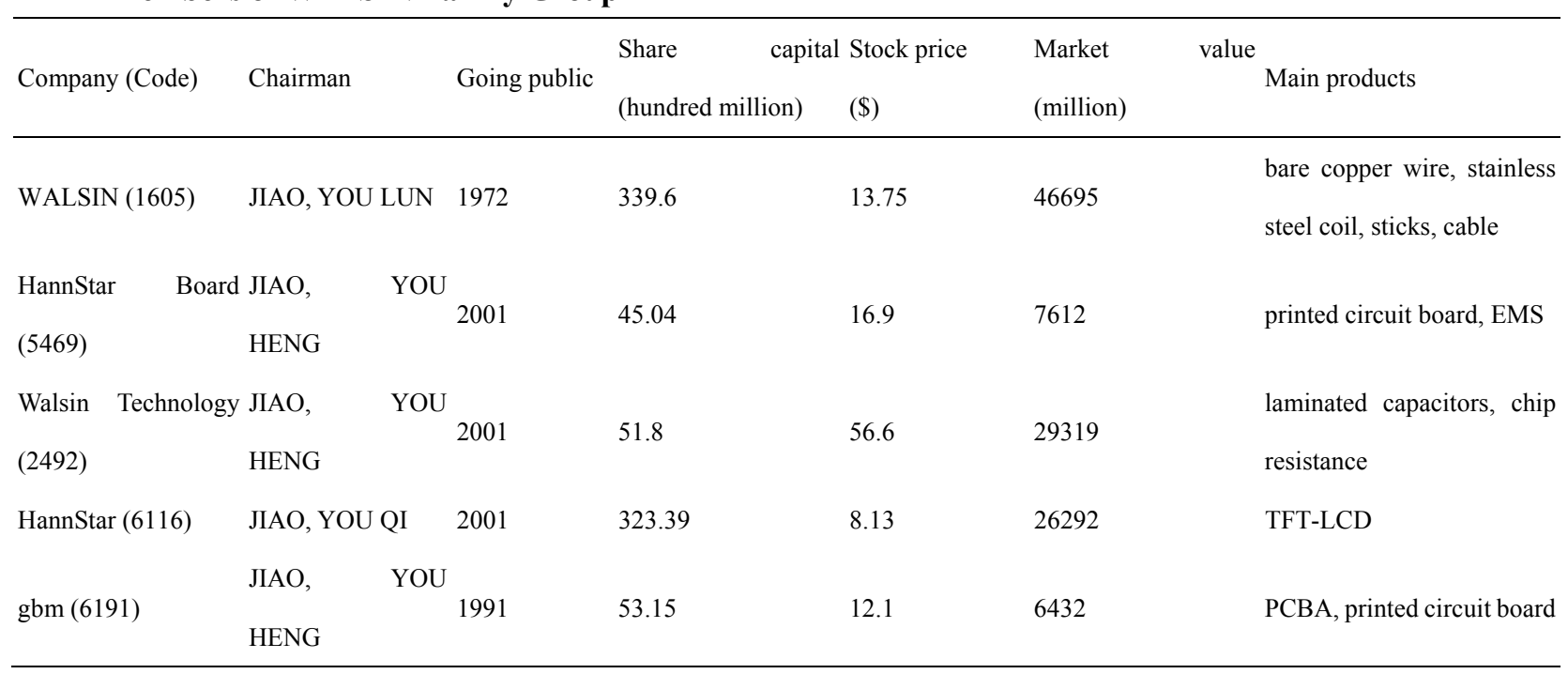




\begin{tabular}{|c|c|c|c|c|c|c|}
\hline Winbond (2344) & JIAO, YOU JUN & 1995 & 358 & 17.2 & 61576 & $\begin{array}{l}\text { DRAM, non-DRAM } \\
\text { memory, logic products }\end{array}$ \\
\hline HannsTouch (3049) & MA, WEI XIN & 2002 & 73.69 & 9.99 & 7362 & touch products \\
\hline Walton Advancec & YOU & 2006 & 48.28 & 14.4 & 6952 & semiconductor package and \\
\hline Engineering (8110) & HENG & & & & & test \\
\hline PSA (6173) & $\begin{array}{l}\text { JIAO, } \\
\text { HENG }\end{array}$ & 2002 & 18.51 & 24.8 & 4591 & $\begin{array}{l}\text { chip capacitors, resistance, } \\
\text { dielectric powder, coil }\end{array}$ \\
\hline Nuvoton (4919) & JIAO, YOU JUN & 2010 & 20.76 & 42.85 & 8894 & general IC, wafer foundry \\
\hline
\end{tabular}

Note: Stock prices are as at 2017.4.21. MA, WEI XIN is the wife of JIAO, YOU QI.

Source: XQ World Winners. 